\title{
Uso de investigação multidisciplinar para diagnóstico de processos erosivos lineares urbanos em uma voçoroca no bairro do Bequimão - São Luís - MA
}

\author{
Use of multidisciplinary investigation for the diagnosis of urban linear \\ processes in a gully in the bequimão neighborhood - São Luís - MA
}

\author{
Felipe Ferreira Oliveira'; Rodrigo da Cruz de Araujo ${ }^{\text {II }}$
}

\begin{abstract}
RESUMO
Processos erosivos lineares têm se mostrado eficazes modificadores da paisagem urbana da ilha de São Luís, em um fenômeno que é fruto da erosão acelerada relacionada à ação antrópica. Devido a sua complexidade, o estudo desse fenômeno exige uma investigação multidisciplinar. O objetivo deste trabalho é verificar a eficiência de uma proposta de diagnóstico multidisciplinar da suscetibilidade à erosão de uma área. Para tanto, foi utilizada como área de referência uma voçoroca localizada no bairro Bequimão, em São Luís (MA). Além disso, busca-se também colaborar para a melhor compreensão em relação à gênese e evolução de um processo erosivo em estágio de voçoroca. A metodologia adotada consiste no estudo multidisciplinar do processo erosivo considerando os seguintes aspectos: caracterização geotécnica, caracterização do meio físico, uso do solo e cobertura vegetal. Os resultados da pesquisa apontam que todos os fatores condicionantes do processo erosivo considerados colaboram para a evolução do fenômeno, podendo-se confirmar que os parâmetros selecionados para a análise multidisciplinar são bons indicativos do processo e, quando tomados em conjunto, permitem identificar com boa confiabilidade áreas suscetíveis à erosão.
\end{abstract}

Palavras-chave: Erosão; Erodibilidade; Solo; Voçoroca

\begin{abstract}
Linear erosive processes have been effective modifiers of the urban landscape of the island of São Luís, in a phenomenon that is fruit of the accelerated erosion caused by the anthropic action. Due to its complexity, the study of this phenomenon requires a multidisciplinary investigation. The objective of this work is to vewrify the efficiency of a proposal of multidisciplinary diagnosis of the susceptibility to erosion of an area. For that, a gully located in the Bequimão neighborhood, in São Luís (MA), was used as reference area. In addition, it is also sought to collaborate to better understand the genesis and evolution of an erosive process in gully stage. The methodology adopted in this work consists of the multidisciplinary study of the erosive process considering the following aspects: geotechnical characterization, characterization of the physical environment, soil use and vegetation cover. The results of the research indicate that all the erosive conditioning factors considered in this work collaborate for the evolution of the phenomenon, confirming that the parameters selected for the multidisciplinary analysis are good indicative of the process and, when taken together, allow identifying with good reliability areas susceptible to erosion.
\end{abstract}

Keywords: Erosion; Erodibility; Soil; Gully

IDoutorando em Matemática (2018) pela Universidade Federal de Minas Gerais (UFMG). E-mail: felipe4ac@gmail.com ORCID: https://orcid.org/0000-0001-7119-4058

IIDocente da Universidade Federal do Maranhão. E-mail: rodrigocruzaraujo@gmail.com ORCID: ～https://orcid.org/0000-0002-1937$\underline{3128}$ 


\section{INTRODUÇÃO}

Dentre as múltiplas manifestações do processo erosivo, uma apresenta-se como objeto de estudo bastante singular devido ao local onde ocorre e ao agente que a desencadeia ou favorece a sua evolução: trata-se da erosão urbana, fenômeno que acontece no perímetro urbano e tem como principal agente no seu desencadeamento e evolução a ação antrópica.

A erosão urbana é fruto da "inadequação do planejamento de uso do solo representada principalmente pelo crescente número de habitações implantadas em locais inadequados e sem elaboração do devido estudo de impacto ambiental" (Magalhães, 2001).

Muitos trabalhos têm sido realizados na ilha do Maranhão direcionados a investigação do potencial erosivo de determinadas áreas degradadas, principalmente as que são produtos da erosão urbana e que apresentam feições erosivas tais como ravinas e voçorocas. Tais estudos, geralmente atacam o aspecto geotécnico do problema, citam-se trabalhos como os de: Sathler et al. (2009), Lisboa et al. (2015) e Silva (2015). Graças a esses e outros trabalhos muitas feições erosivas, com o destaque para as voçorocas, estão catalogadas na ilha do Maranhão.

Quando se trata da investigação do potencial erosivo de uma área como um todo é necessário considerar outras ferramentas além do aspecto geotécnico na investigação, pois as feições erosivas são produtos não apenas das características intrínsecas do solo, mais também do clima, geologia, geomorfologia, cobertura vegetal, uso do solo (ação antrópica). Desse modo, fica clara a necessidade de uma investigação multidisciplinar.

A fim de contribuir no estudo da erosão urbana o objetivo principal deste trabalho é verificar a eficiência de uma proposta de diagnóstico multidisciplinar da suscetibilidade à erosão de uma área. A referida proposta de diagnóstico consiste em investigação do meio físico (influência do clima e da geomorfologia), caracterização geotécnica do solo (correlação entre as propriedades intrínsecas do solo com o seu potencia erosivo) e estudo da utilização do solo e sua cobertura. Para tanto, foi utilizada como área de referência uma voçoroca localizada no bairro Bequimão, em São Luís (MA). 
Assim, têm-se então os seguintes objetivos específicos: caracterizar os aspectos geotécnicos do solo; analisar o uso e cobertura da terra; identificar, cadastrar e caracterizar os processos erosivos lineares; avaliar a suscetibilidade a erosão.

Para tanto, o artigo apresenta inicialmente uma revisão bibliográfica sobre processos erosivos e seus fatores condicionantes; em seguida é descrita a metodologia utilizada, a qual consiste da investigação multidisciplinar; segue-se com uma descrição dos diversos aspectos pertinentes relativos à área selecionada como referência; apresentação e análise dos resultados e as considerações finais.

\section{EROSÃO}

Etimologicamente a palavra erosão é deriva da palavra erodere, proveniente do latim, que significa corroer, devorar e etc. (Mortari, 1994), portanto, todos os processos de desgaste realizados pela água, vento e geleiras que são denominados de processos erosivos. Na literatura, diversos conceitos podem ser encontrados, tais como os apresentados por Pastore (1986), Vilar e Prandi (1993), Marçal (2000), Guerra (1995), Gray e Leiser (1982).

O termo erosão neste trabalho será entendido como o processo que remove as camadas superficiais de solo e transporta-as através dos agentes erosivos (tais como rios, mares, vento e chuva), ocorrendo em duas fases (remoção de partículas e transporte ) e cujo produto é o sulco, a ravina, ou a voçoroca.

Distinguem-se ainda dois tipos de erosão: a natural e a acelerada. Barros (1956) destaca o prejuízo da erosão acelerada, danos algumas vezes irreparáveis para uma geração tendo em vista o tempo necessário para o solo se regenerar. 0 desequilíbrio pode ser ativado por alterações nas condições de clima, alterações na geologia, pela ação conjunta dos fatores naturais e antrópicos ou apenas pela ação do homem. Quando desencadeada pela ação do homem geralmente está relacionado ao uso inadequado do solo, como: desmatamento, crescimento urbano desordenado, agricultura, obras de grande porte (fábricas, barragens), etc.

\subsection{Fatores Condicionantes}

Para investigar o potencial erosivo de determinada área é necessário considerar as várias variáveis que estão relacionadas a gênese desse processo, 
portanto, fatores como clima, geologia, geomorfologia, características do solo, cobertura vegetal e uso do solo são imprescindíveis para realizar tal estudo e por isso serão apresentados a seguir.

\subsubsection{Clima}

No que tange ao processo erosivo, o clima contribui com dois agentes, chuva e vento, sendo ambos responsáveis pela desagregação das partículas e seu transporte. A precipitação é o elemento mais importante do clima no que se refere aos processos erosivos. Seu impacto sobre o solo sofre forte influência do vento. Segundo Jesus (2013) o impacto das gotas de chuva sobre o solo favorece a desagregação das partículas do solo, além do que a água também atuará como agente de transporte dessas partículas.

A ação erosiva da chuva depende de sua distribuição e intensidade no tempo e no espaço. A capacidade erosiva da chuva e denominada de erosividade (Almeida Filho e Ridente Junior, 2001).

Mesmo com totais de precipitação iguais, chuvas pouco intensas de longa duração provocam menos danos se comparadas às chuvas curtas e muito intensas (Moreira e Pires Neto, 1998).

Chuvas torrenciais, precedidas por períodos chuvosos responsáveis pela saturação do solo, determinam em locais de escoamento concentrado feições erosivas que se expandem com muita velocidade (Infanti Junior e Fornasari Filho, 1998).

\subsubsection{Geomorfologia}

A influência do relevo na erosão está associada principalmente à declividade, ao comprimento e à forma de vertente. Quanto maior o declive, maior a velocidade do escoamento. Se o comprimento de vertente também for extenso, essa velocidade se amplia ainda mais (Jesus, 2013).

Bertoni e Lombardi Neto (2008) destacam que um terreno com 20,00 m de comprimento e $20,00 \%$ de declividade tem a mesma taxa de perda de terra que um terreno de 180,00 m de comprimento e 1,00\% de declividade, nas mesmas condições de chuva, tipo de solo e tipo de cobertura e manejo. 
As vertentes são caracterizadas pela forma do seu perfil e pelas suas curvas de níveis, que podem ser côncavas ou convexas. Troeh (1965, apud Casseti, 2005) apresenta uma classificação que considera não só as formas em perfil, mas também as formas em planta (Figura 1), onde se distingue:

Vertentes com curvas de nível côncavas e perfil côncavo (tipo I);

Vertentes com curvas de nível côncavas e perfil convexo (tipo II);

Vertentes com curvas de nível convexas e perfil convexo (tipo III);

Vertentes com curvas de nível convexas e perfil côncavo (tipo IV).

Figura 1 - Classificação de vertentes segundo a forma em perfil e em mapa segundo Troeh, (1965 apud Casseti, 2005).

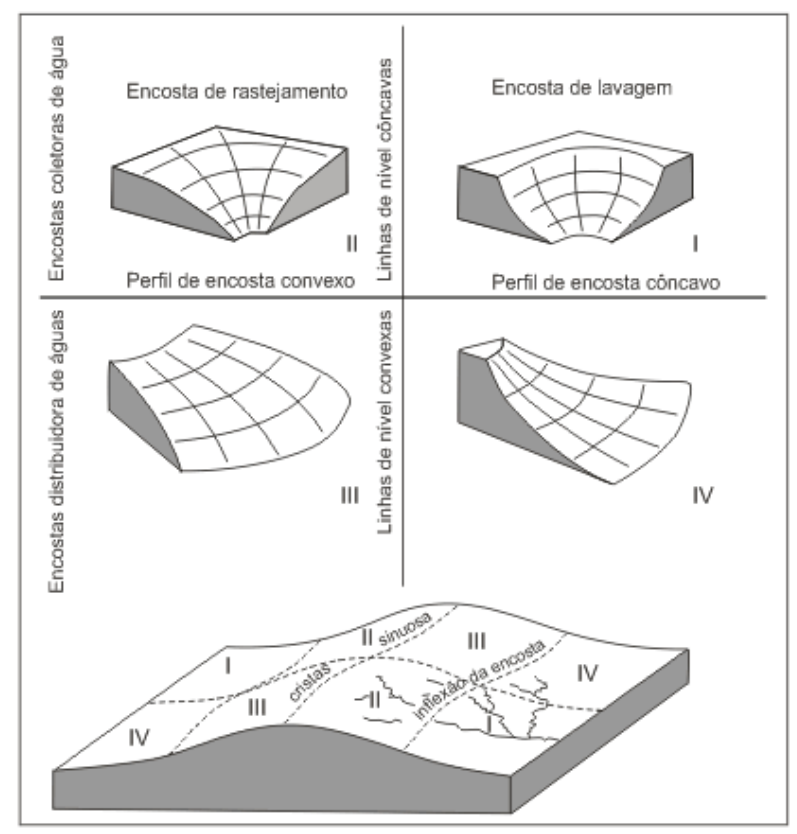

Fonte: Troeh, (1965 apud Casseti, 2005).

Vertentes convexas, retilíneas e côncavas influenciam, de maneira distinta, no volume e na velocidade do escoamento superficial (Jesus, 2013). As vertentes com curvas de nível côncavas e perfil côncavo e as vertentes com curvas de nível côncavas e perfil convexo, por exemplo, são concentradoras do fluxo superficial. As vertentes com curvas de nível convexas e perfil convexo e as vertentes com curvas de nível convexas e perfil côncavo fazem com que as linhas de fluxo d'água sejam dispersadas.

Portanto, as vertentes do tipo I e II induzem mais facilmente a ocorrência de incisões erosivas. 


\subsubsection{Características do Solo}

O solo é um recurso básico que suporta toda a cobertura vegetal da Terra?, sem a qual os seres vivos não poderiam existir. Nessa cobertura incluem-se, além das culturas, todos os tipos de árvores, gramíneas, raízes e herbáceas que podem ser utilizadas pelo homem (Bertoni, 1968). Além disso, "a formação de um solo é função da rocha de origem, da ação dos organismos vivos, do clima, da fisiografia e do tempo" (JENNY, 1941).

O conhecimento das características físicas de um solo é fundamental para entender a dinâmica da erosão, pois, segundo Bertoni e Lombardi Neto $(2008$, p.82) "alguns solos erosionam mais que outros (...) essa diferença, devida às propriedades do próprio solo, é denominada erodibilidade do solo" o que resulta que solos com características diferentes são erodidos com intensidades diferentes. A textura, por exemplo, é uma característica de grande relevância no estudo da erodibilidade.

Segundo Guerra e Botelho (1996, p. 101) "Os teores de areia, silte e argila, atuam sobre a erosão, à medida que podem oferecer maior ou menor resistência ao destacamento (detachmemt) e ao próprio transporte pela água resultante do escoamento superficial, difuso ou concentrado". Ainda segundo esses autores podemse relacionar algumas faixas dessas frações com a susceptibilidade a erosão.

A areia fina e o silte são as frações granulométricas que apresentam maior facilidade de serem erodidas, pois não possuem muita coesão, nem peso suficiente que dificulte a ação da água, tanto no splash, como no escoamento superficial Guerra e Botelho (1996, p. 101).

A areia grossa e a argila são as frações granulométricas que oferecem maior resistência à erosão. As areias, devido ao seu diâmetro, apresentam um peso maior que dificulta a ação da água, enquanto as argilas, devido à sua coesão, em especial quando combinadas com matéria orgânica, formam agregados estáveis, que também oferecem resistência à ação da água Guerra e Botelho (1996, p. 101).

Muitas vezes, a avaliação do potencial de erosão de um solo é feita não de forma direta, mas sim por meio de medidas indiretas que possam representá-la. Assim, tem sido comum a apresentação de propostas buscando relacionar a erodibilidade dos solos com suas características (Araujo e Campos, 2013). 
O solo pode ser classificado simplesmente pela sua textura. As classes texturais do solo guardam relação com a erodibilidade.

Araujo e Campos (2013), a partir da comparação dos resultados de seu estudo junto a outros solos relatados na literatura como os trabalhos de Fácio (1991), Fonseca e Ferreira (1981), Lima (1999) e Santos (1997) apresentam uma proposta de separação de duas zonas, indicando a provável tendência de comportamento dos solos, conforme Figura 2.

Já Bouyoucos (1935), relaciona a erodibilidade do solo como apresentado na Equação 1 que utiliza as porcentagens de areia, silte e argila (Bouyoucos, 1935):

$$
\mathrm{E}=\frac{\% \text { areia }+\% \text { silte }}{\% \text { argila }}
$$

Essa equação parte do pressuposto de que a argila age como ligante, dificultando o destacamento das partículas do solo, e que as partículas mais grossas que a areia não seriam destacáveis.

Figura 2 - Proposta de separação de zonas de erodibilidade utilizando o triângulo textural.

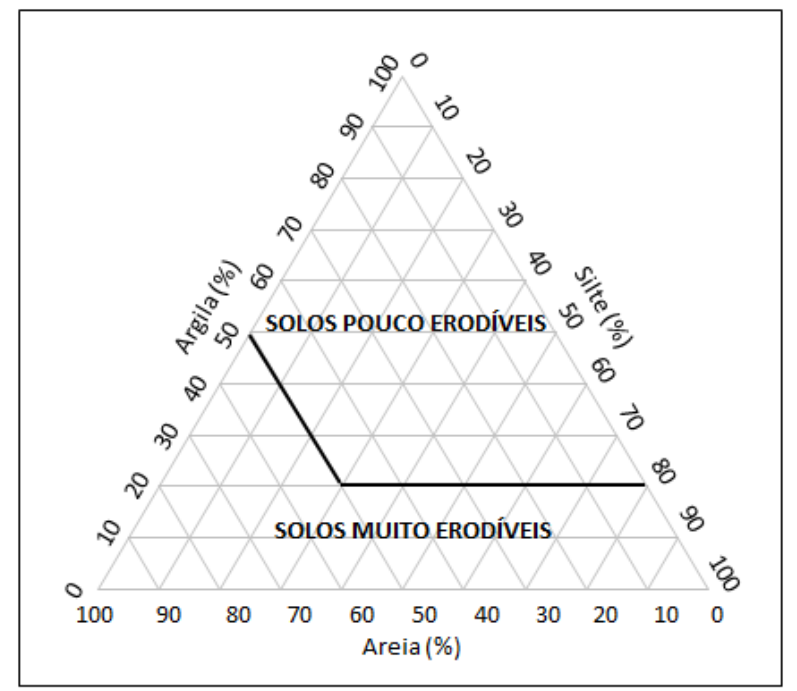

Fonte: Adaptado de Araujo e Campos (2013).

Mannigel et al. (2002) classificaram os valores do fator erodibilidade do solo (K) nas seguintes classes: baixo: com valores entre 0,01 e 0,03 t.ha.h/ha.MJ.mm; médio: com valores entre 0,03 e 0,06 t.ha.h/ha.MJ.mm; alto: com valores acima de 0,06 t.ha.h/ha.MJ.mm. Tais valores são obtidos por intermédio da Equação 2:

$$
\mathrm{K}=\left(\frac{\text { \%areia }+\% \text { silte }}{\% \text { argila }}\right) / 100
$$


Meireles (1967) afirma que solos fortemente erodíveis apresentam os seguintes comportamentos: fortemente erodiveis: $\mathrm{LL} \leq 21,00 \%$ e IP $\leq 8,00 \%$ e $\%$ passa \#200

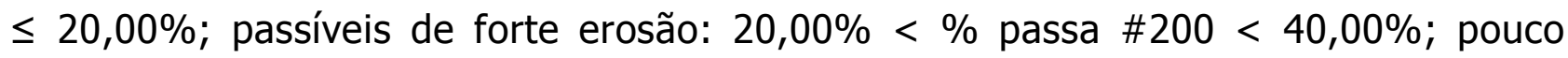
erodíveis: \% passa \#200 > 40,00\%.

Outra proposta para avaliar a erodibilidade dos solos relacionando índice de plasticidade (IP) e Coeficiente de Uniformidade (Cu) é apresentada na Tabela 1 (Santos, 2001).

Tabela 1 - Critérios adotados por Santos (2001) quanto à relação erodibilidade, IP (índice de plasticidade) e Coeficiente de Uniformidade (Cu).

\begin{tabular}{|c|c|c|c|}
\hline IP & Erodibilidade & $\mathrm{Cu}$ & Erodibilidade \\
\hline IP $>15$ & $\begin{array}{c}\text { Boa resistência } \\
\text { a erosão }\end{array}$ & $\mathrm{Cu}<5$ & Solos erodíveis \\
\hline $15>$ IP $>6$ & $\begin{array}{c}\text { Média resistência } \\
\text { a erosão }\end{array}$ & $5<\mathrm{Cu}<15$ & $\begin{array}{c}\text { Solos de média } \\
\text { erodibilidade }\end{array}$ \\
\hline IP $<6$ & $\begin{array}{c}\text { Baixa resistência } \\
\text { a erosão }\end{array}$ & $\mathrm{Cu}>15$ & $\begin{array}{c}\text { Solos de baixa } \\
\text { erodibilidade }\end{array}$ \\
\hline
\end{tabular}

Fonte: Adaptado de Santos (2001).

\subsubsection{Cobertura Vegetal}

A cobertura vegetal desempenha um papel importante no controle de erosões, pois minimiza os efeitos do impacto da gota de chuva e do escoamento superficial. Isso é explicado pelo fato de que quando a gota cai na vegetação divide-se em gotas menores e começa a valer a energia potencial gravitacional não mais da altura da nuvem ao solo, mas da altura da vegetação ao solo e agora de massas menores, diminuindo o impacto (splash). No caso do escoamento a vegetação serve como obstáculo, dissipando assim a energia cinética (Silva, 2007).

Segundo Salomão e Iwasa (1995), a cobertura vegetal é responsável por: proteger o solo do impacto direto das gotas de chuva; dispersar a energia do deflúvio; aumentar a infiltração através dos poros produzidos pelo sistema radicular, e aumentar a capacidade de retenção de água.

Na Tabela 2 é possível notar a importância da cobertura vegetal, pois, em áreas vegetadas, o escoamento superficial tende a ser inferior a 50,00\%. Já se a área estiver impermeabilizada, a porcentagem de infiltração é inferior a 5,00\%, o restante 
escoando superficialmente e agindo no processo erosivo, Villela e Mattos (1975) apud Jorge e Uehara (1998).

Tabela 2 - Coeficientes de escoamento superficial segundo os tipos de cobertura do terreno.

\begin{tabular}{|c|c|}
\hline Características da bacia & Coeficiente de escoamento \\
\hline Superfícies impermeáveis & $90-95 \%$ \\
\hline $\begin{array}{c}\text { Florestas e matas de } \\
\text { árvores de folhagem } \\
\text { em terrenos com } \\
\text { declividades variadas }\end{array}$ & $5-50 \%$ \\
\hline
\end{tabular}

Fonte: Villela e Mattos (1975 apud Jorge e Uehara, 1998) - adaptado.

É possível visualizar o potencial da cobertura vegetal no combate a erosão na equação da perda do solo. A equação da perda do solo segundo Wischmeier e Smith (1978) é apresentada seguir:

$A=R \cdot K \cdot L \times S * C \times P$

Onde:

$\mathrm{A}=$ perda de solo calculada por unidade de área, t/há;

$\mathrm{R}$ = fator chuva;

$\mathrm{K}$ = fator erodibilidade do solo;

$\mathrm{L}=$ fator comprimento de declive;

$\mathrm{S}=$ fator grau de declividade;

$\mathrm{C}=$ fator uso e manejo;

$\mathrm{P}=$ fator prática conservacionista.

Destaca-se ainda na Equação 3 que L e S juntos formam um único elemento que é o fator topográfico.

$$
\text { LS }=0,00984 C^{0,63} D^{1,18}
$$

Onde:

LS = fator topográfico;

$\mathrm{C}=$ comprimento da rampa;

$\mathrm{D}=$ grau de declividade em porcentagem. 
Bertoni e Lombardi Neto (2008) explicam que o fator (P) relaciona a intensidade esperada das perdas com certa prática conservacionista e aquelas que ocorreriam quando a cultura está plantada no sentido do declive (morro abaixo).

A Tabela 3 relaciona as principais práticas conservacionistas com seus respectivos valores de $(P)$ obtidos pela Seção de Conservação do Solo do Instituto Agronômico.

Tabela 3 - Valor de P para algumas práticas conservacionistas.

\begin{tabular}{|c|c|}
\hline Prática Conservacionista & Valor de P \\
\hline Plantio morro abaixo & 1 \\
\hline Plantio em contorno & 0,5 \\
\hline $\begin{array}{c}\text { Alternância de campinas + plantio em } \\
\text { contorno }\end{array}$ & 0,4 \\
\hline $\begin{array}{c}\text { Cordões de vegetação } \\
\text { permanente }\end{array}$ & 0,2 \\
\hline
\end{tabular}

Fonte: Bertoni e Lombardi Neto (2008).

Observa-se que uma medida conservacionista de um plantio em contorno pode diminuir a perda de solo em até $50,00 \%$. Esse dado evidencia a relevância da cobertura vegetal na conservação do solo, de onde também se pode inferir que a sua ausência é contribui significativamente na evolução do processo erosivo.

\subsubsection{Uso do Solo}

Criar condições para que se dê a erosão parcial ou total é o mais negativo dos efeitos do homem sobre o solo (Drew e Dos Santos, 1994). Segundo Jesus (2013) a principal dessas condições é o desmatamento, que é uma das primeiras formas de atuação humana que impacta o meio ambiente, resultando na perda da proteção natural do terreno. Na falta da cobertura vegetal, é necessário que se implemente, tanto nas áreas rurais como nas urbanas, infraestrutura adequada para evitar o fluxo concentrado do deflúvio.

Ainda segundo Jesus (2013) em áreas urbanas, as primeiras recomendações a serem feitas são: ocupação do solo se dê de modo progressivo e acompanhado da implantação de infraestrutura, evitando-se a ocupação esparsa e os desmatamentos e arruamentos inoportunos; evitar os sistemas de arruamento com ruas muito longas perpendiculares às curvas de nível, ocupação de cabeceiras de drenagem, fundos de 
vale e áreas muito inclinadas; disciplinamento das águas superficiais com instalação de sarjetas, bocas de lobo, galerias condutoras e equipamentos dissipadores da energia do escoamento.

Segundo Iwasa e Fendrich (1998), a maioria dos municípios brasileiros é afetada por erosões lineares, causadas principalmente pela concentração de águas do escoamento superficial. Jesus (2013) observa que o grande detonador da erosão urbana é o escoamento superficial concentrado sobre áreas impermeabilizadas, com sistema de drenagem ineficiente ou inexistente assim como o lançamento de águas em locais inadequados, como a meia vertente, ou em cabeceiras de drenagem também são grandes causadoras de erosão.

As ações antrópicas correspondem às práticas gerais realizadas pelo homem, e têm grande importância no tipo e intensidade dos processos erosivos. Segundo Mota (1991), atividades desenvolvidas pelo homem contribuem para a aceleração do processo de erosão do solo, destacando-se, por exemplo: desmatamento de áreas extensas, de terrenos de encostas, da mata ciliar, de locais de solos erodíveis, entre outros; práticas agrícolas como monoculturas, culturas não perenes, plantio em encostas, cultivo intensivo, uso de máquinas e implementos agrícolas; queimadas; agropecuária: criação excessiva de animais em áreas de pastagem (sobre pastoreio); movimentos de terra: escavações e aterros; alterações no escoamento natural das águas: barragens; aterros; alterações nos trajetos decursos d'água, drenagem artificial; impermeabilização do solo: construções, pavimentações, compactação; atividades de mineração; execução de obras: desmatamentos; movimentos de terra; áreas de empréstimos; impermeabilização; alterações no escoamento das águas.

\section{METODOLOGIA}

A metodologia usada para investigar a feição erosiva localizada do bairro Bequimão consta de três aspectos. São eles: caracterização do meio físico (influência do clima e da geomorfologia); caracterização geotécnica (estudo do solo via ensaios); cobertura vegetal e uso do solo. A caracterização do meio físico, visando relacioná-la a processos erosivos é parte do trabalho de vários autores tais como: Almeida Filho e Ridente Júnior (2001), Moreira e Pires Neto (1998), Iwasa e Fendrich (1998), Salomão e Iwasa (1995), Troeh (1996), Casseti (2005). De modo geral, tais autores 
concordam que a capacidade da erosão de atuar em determinadas áreas depende das características de elementos climático, geomorfológico e pedológico, por isso, estudaremos esse elementos a fim de entender o processo erosivo em análise. Nesse sentido, buscamos informações tais como regime e volume de chuva, topografia e relevo.

A caracterização geotécnica é largamente utilizada na literatura para relacionar a erodibilidade do solo com suas propriedades geotécnicas. Angulo (1983), por exemplo, estudou a relação entre a erodibilidade e algumas propriedades de solos brasileiros. Citam-se ainda alguns trabalhos de correlacionar propriedades geotécnicas e potencial erosivo dos solos os dos autores: de Araujo e Campos (2013), Mannigel et al. (2002), Meireles (1967) e Santos (2001).

A caracterização do uso e cobertura do solo também consiste em fator fundamental para o processo, conforme apontam Silva (2007), Salomão e Iwasa (1995), Jorge e Uehara (1998), Drew e Dos Santos (1994). Em seus trabalhos, os referidos autores afirmam que a cobertura do solo dificulta a ação erosiva da água e que a ocupação inadequada do solo pode favorecer a atuação do processo erosivo. Assim, o trabalho é dividido em três etapas: trabalho de campo, trabalho de laboratório e de trabalho de gabinete.

O trabalho de campo consta de coleta de amostras, caracterização da feição erosiva, caracterização do meio físico e caracterização do uso e cobertura do solo. A amostra foi retirada buscando-se coleta de materiais mais característicos da voçoroca. A partir da coleta das amostras serão realizados os ensaios de laboratório.

Ainda na etapa de campo, foram levantadas informações sobre a feição erosiva estudada como comprimento, algumas características do solo, aspectos sobre o seu entorno, registros fotográficos e outras informações relevantes. Também foram analisadas características da topografia e da forma da vertente e buscados indícios da influência do clima no processo erosivo.

As informações adquiridas por meio da inspeção local revelaram também como o solo estava sendo utilizado e qual o estado da cobertura vegetal. Ainda será comparado com informações históricas da área. As informações adquiridas aqui 
serviram de dados de entrada para gerar parâmetros sobre o potencial erosivo da área estudada.

Em relação à segunda etapa, o trabalho de laboratório consiste de ensaios de caracterização geotécnica do solo retirado da feição erosiva V01. Algumas classificações dos solos com respeito à erosão exigem que sejam realizados ensaios geotécnicos como Limite de Liquidez normalizado pela NBR 6459 (ABNT,1984a), Limite de Plasticidade normalizado pela NBR 7180 (ABNT, 1984b) e Granulometria normalizado pela NBR 7181 (ABNT,1984C).

Por fim, a última etapa inclui análise dos ensaios, compilação de dados e relatório fotográfico. Os resultados obtidos por meio dos ensaios das amostras de solo são aplicados às propostas que correlacionam as propriedades intrínsecas do solo à erodibilidade, existentes na literatura. Os demais fatores condicionantes (vegetação, clima, uso do solo e geomorfologia) são analisados como indicadores de suscetibilidade a erosão do local de estudo, procurando-se avaliar a influência de determinado fator local no desenvolvimento do processo erosivo, com base nas características favoráveis e desfavoráveis relatadas na literatura. Associando tais análises tem-se o produto final deste trabalho que é o diagnóstico da suscetibilidade a erosão da área baseado em fatores multidisciplinares.

Devido às características da área de estudo, foi considerado apenas o agente hídrico manifestado na forma de chuva, uma vez que a forma erosiva estudada neste trabalho é a voçoroca que é um tipo de erosão linear produto da ação pluvial.

\section{4. ÁREA DE ESTUDO}

A área investigada localiza-se no bairro do Bequimão, no município de São Luís - MA, estando compreendida entre as coordenadas 2०32'09.1"S, 44'15'20.4"W e 2³1'51.5"S 44²15'03.1"W (Figura 3). A área é circundada pelo Condomínio A, Condomínio $B$, mangue e algumas residências. Considerando somente a área que contempla as feições erosivas (delimitada em azul na Figura 3), verifica-se que a topografia é de declive, podendo ser considerada como uma rampa com 
aproximadamente 300,00 m de comprimento e com um desnível de 20,00 m, totalizando uma declividade média de 6,67\%.

$\mathrm{Na}$ perspectiva do estudo da erosão, o Condomínio A, bem como o seu entorno, é uma área desprovida de infraestrutura necessária (saneamento, drenagem, arruamento) a combater o processo erosivo, potencializando, assim, os impactos da ação antrópica. Observa-se, portanto, que a área estudada está inserida em perímetro urbano, evidenciando, dessa forma, a forte influência da ação antrópica.

Figura 3 - Ilustração dos componentes da área de estudo.

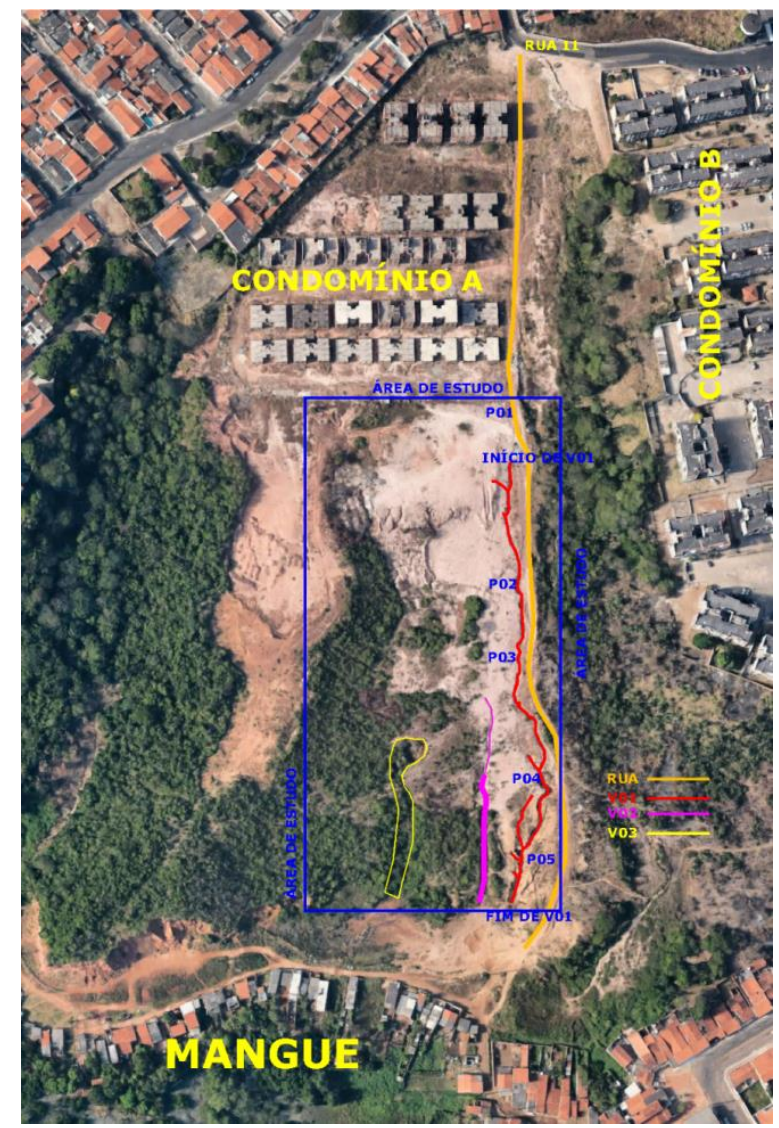

Fonte: Google Earth (2017). Adaptada pelos autores.

$\mathrm{Na}$ área estudada foram identificadas três feições erosivas em estágio de voçoroca, que doravante serão designadas por V01, V02 e V03 (Figura 3). As três voçorocas apresentam praticamente as mesmas condições de exposições aos agentes erosivos, com a exceção da V01 que praticamente não apresenta cobertura vegetal. Uma particularidade dessas três voçorocas é que elas são aproximadamente paralelas e terminam aproximadamente numa mesma região. Podemos observar também que é 
neste lugar que V01 é mais larga e mais profunda, conforme se pode verificar na Figura 4.

Figura 4 - Região com maior concentração de feições erosivas.

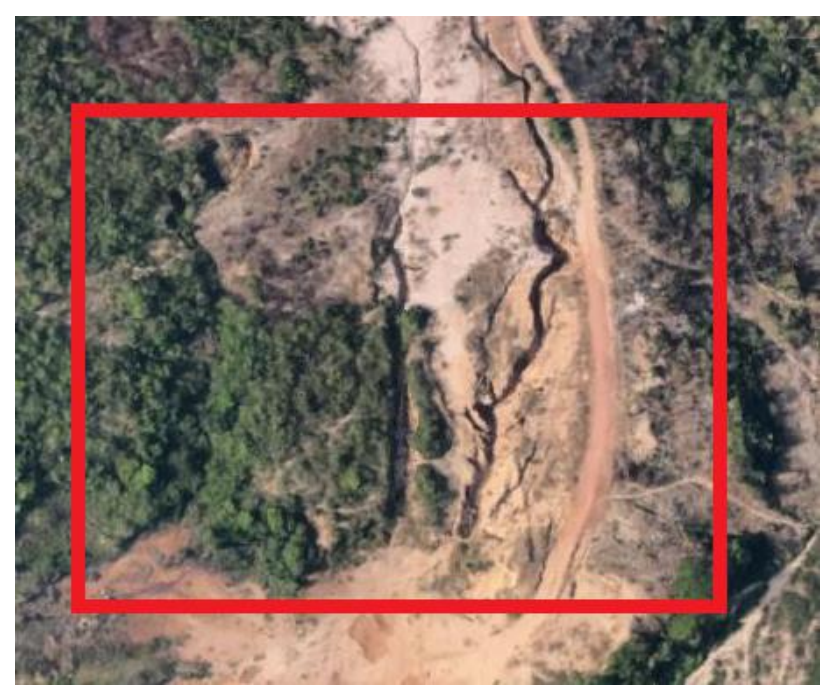

Fonte: Google Earth (2017).

Para melhor caracterização da voçoroca V01 estão apresentados nas Figuras 5, $6,7,8$ e 9 alguns registros de pontos relevantes no estudo da área.

Figura 5 - Vista no sentido P04-Mangue.

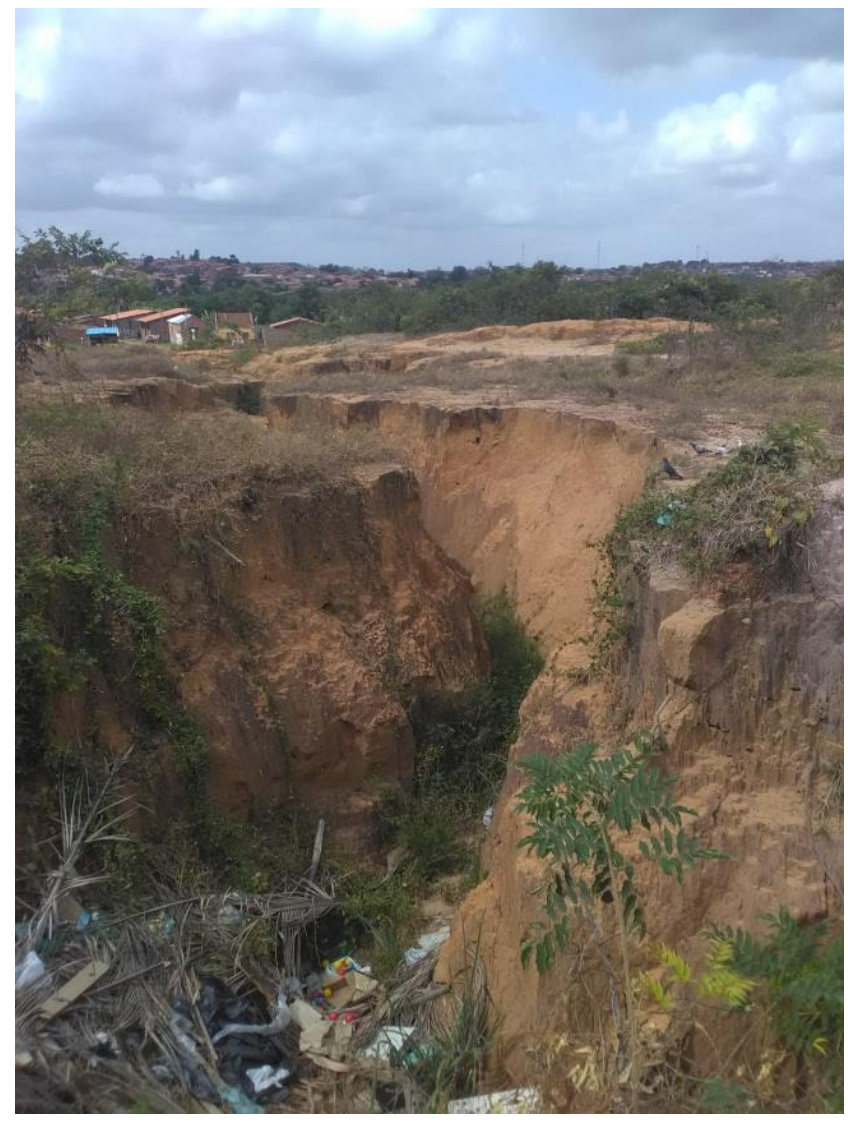

Fonte: Acervo particular dos autores (dezembro de 2017). 
16 | Uso de investigação multidisciplinar para diagnóstico de processos erosivos lineares urbanos em uma voçoroca no bairro do Bequimão - São Luís - MA

Figura 6 - Vista no sentido P03-Mangue.

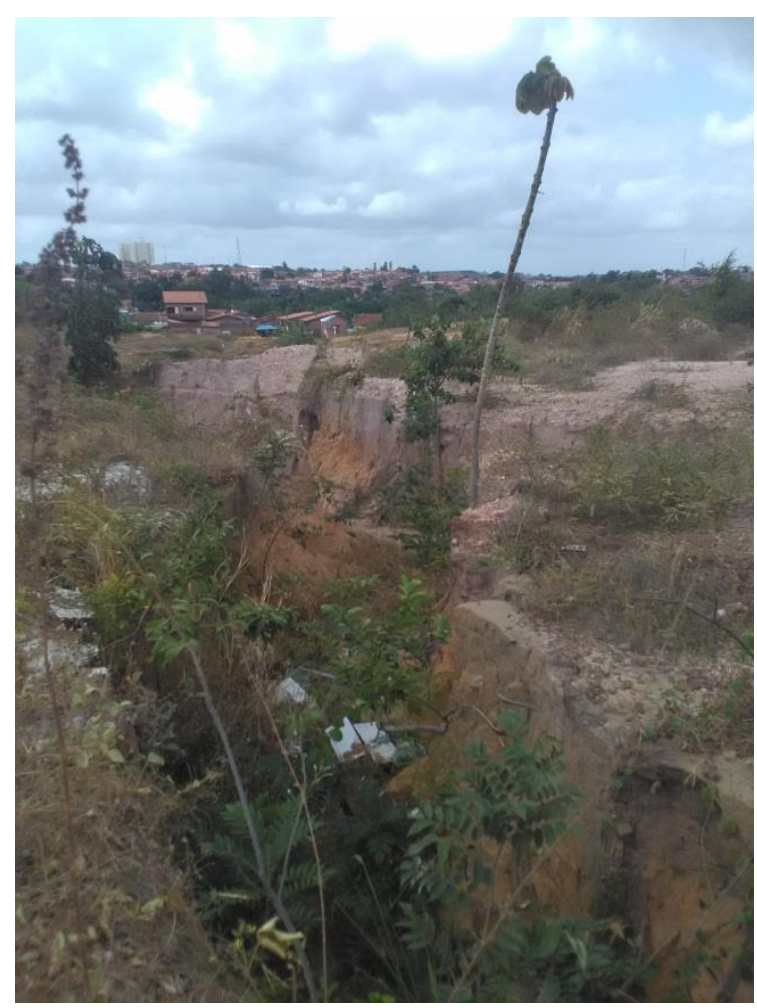

Fonte: Acervo particular dos autores (dezembro de 2017).

Figura 7 - Vista no sentido P05-Mangue

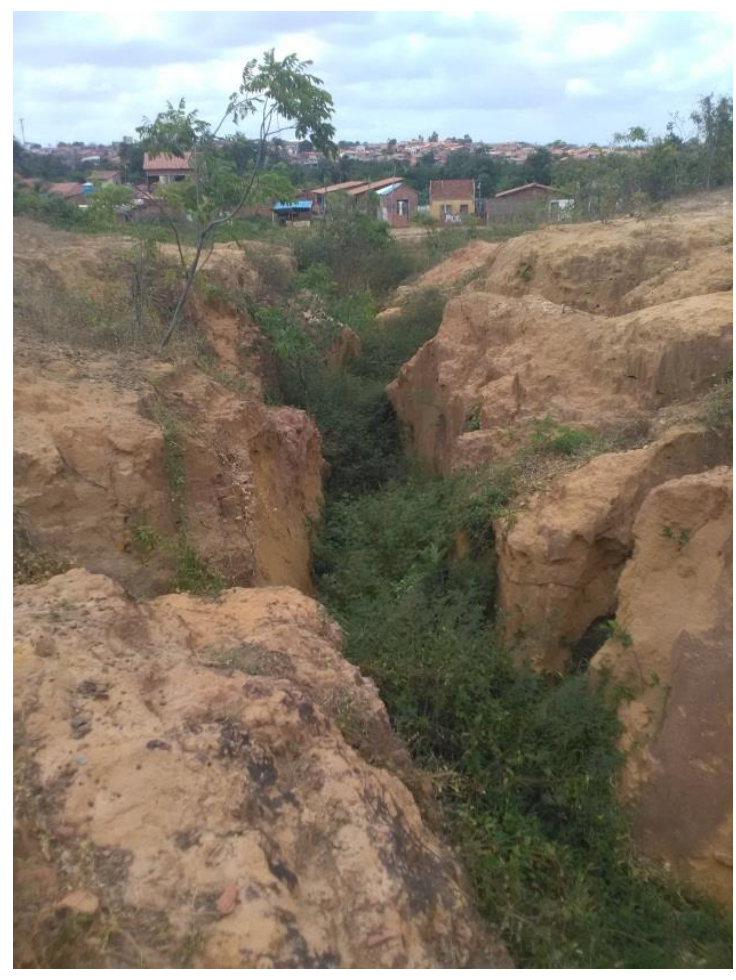

Fonte: Acervo particular dos autores (dezembro de 2017). 
Figura 8 - Fim da voçoroca.

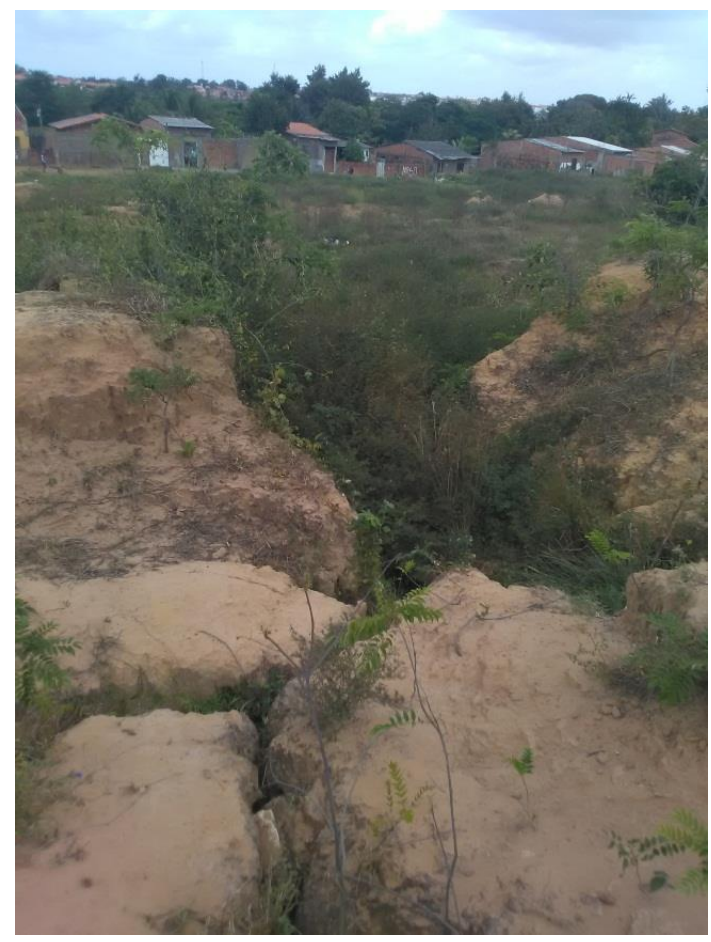

Fonte: Acervo particular dos autores (dezembro de 2017).

Figura 9 - Vista no sentido P04-Mangue.

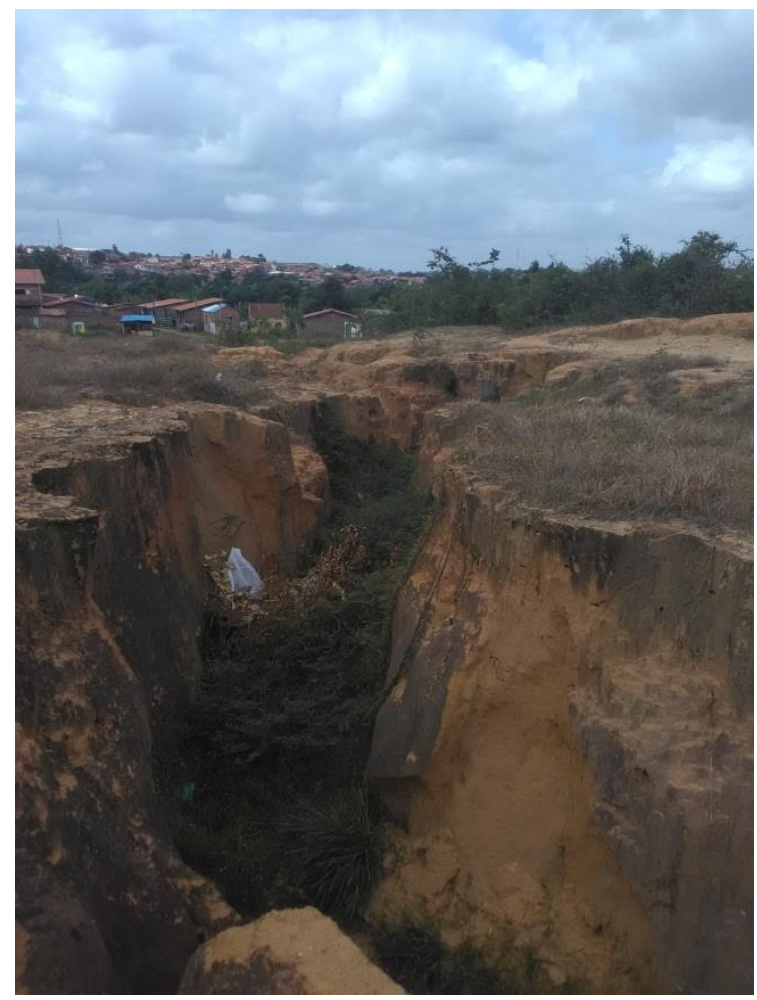

Fonte: Acervo particular dos autores (dezembro de 2017). 
A feição erosiva V01 tem uma extensão de aproximadamente 250,00 m. Como é possível observar nas Figuras 5, 6 7, 8, e 9 a voçoroca é desprovida de cobertura vegetal. O solo predominante no corpo da feição erosiva tem cor amarela. É possível identificar também o despejo de lixo ao longo da voçoroca, evidenciando a atuação da ação antrópica, conforme Figuras 5 e 6.

\section{APRESENTAÇÃO DOS RESULTADOS}

\subsection{Clima}

Dentro do perímetro estudado foram identificadas três feições erosivas em estágio de voçoroca. Esse tipo de feição erosiva denuncia que o agente pluvial é um agente ativo no local, visto que a voçoroca é um produto da erosão pluvial.

Figura 10 - Total pluviométrico trimestral observado jan/fev/mar de 2017 (mm).

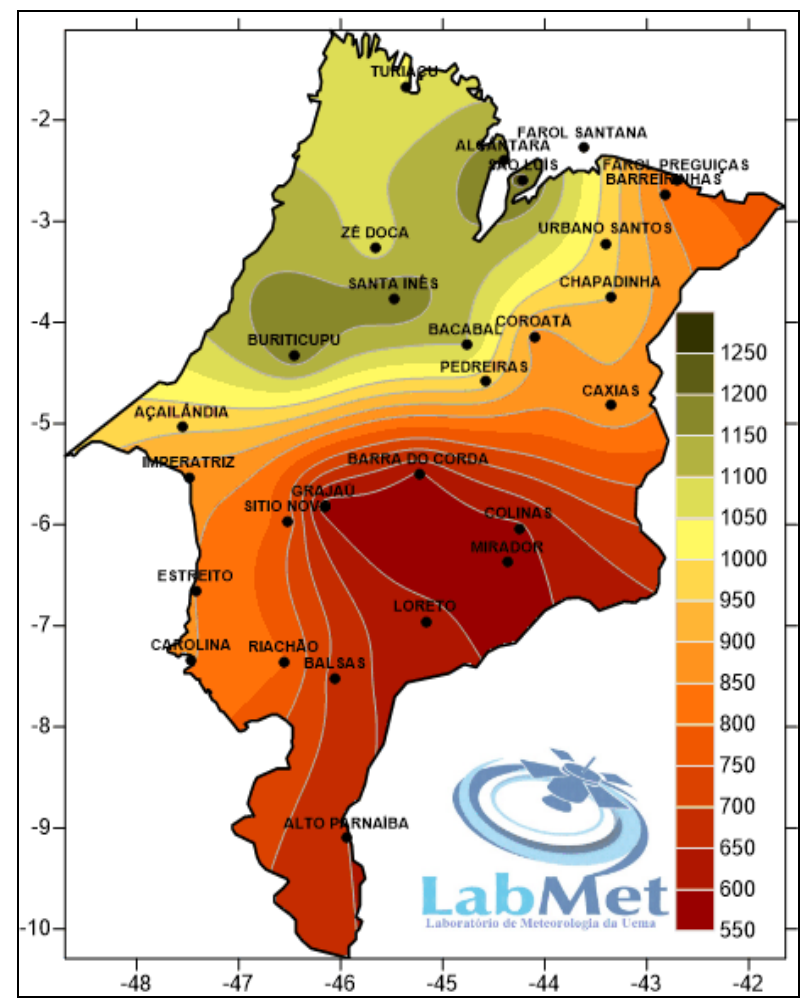

Fonte: Núcleo Geoambiental da UEMA (2017).

Chuvas intensas (quando se tem mais volume de água em um menor intervalo de tempo) possuem uma maior erosividade do que chuvas longas com pouco volume. Na região de São Luís as chuvas intensas são comuns no início do período chuvoso. Segundo o Informativo Climático de Janeiro de 2017 publicado pelo Núcleo Geoambiental da UEMA (Figura 10), o início do mês de janeiro de 2017 foi marcado 
por alguns fenômenos meteorológicos expressivos como chuva de granizo, nuvens do tipo rolo, vendaval e chuvas fortes. Na noite dia 18 de janeiro de 2017 uma grande área de instabilidade se formou em todo o extremo norte do Maranhão (área de estudo) e causou muita chuva na região e áreas adjacentes, provocando o episódio de chuva mais intenso dos últimos anos para o mês de janeiro, com total de 130,60 mm de chuva acumulados em poucas horas em São Luís.

Ainda segundo o Núcleo Geoambiental a climatologia do trimestre jan/fev/mar mostra que normalmente os maiores volumes de chuvas se encontram no extremo norte do estado, apresentando volumes superiores a $1.000 \mathrm{~mm}$, como pode ser observado na Figura 10.

\subsection{Geomorfologia}

A área de estudo pode ser concebida como uma "grande rampa" com declividade no sentido do mangue. A topografia do terreno favorece o escoamento no sentido Condomínio A-Mangue. Do início de V01 (cota de 28,00 m) até o fim de V01 (cota de 8,00 m) (ver Figura 5) o comprimento de rampa é de 300,00 m totalizando uma declividade média de 6,67\%.

Conferindo a Equação 4, referente ao fator topografia na equação da perda de solo de Wischmeier e Smith (1978), verifica-se que o acréscimo de declividade é mais significativo do que o acréscimo do comprimento de rampa para a evolução do processo erosivo. Considerando a área do Condomínio A, têm-se ainda mais 200,00 $\mathrm{m}$ de rampa, totalizando assim 500,00 m. Esse total é significativo, pois a água ganha velocidade ao longo de toda essa extensão, visto que não há barreiras para dissipar a energia do movimento da água.

A vertente foi classificada como sendo do Tipo II com a ressalva que as curvas de nível são levemente côncavas. Portanto a vertente é concentradora do fluxo superficial, contribuindo para a formação do processo erosivo.

\subsection{Caracterização Geotécnica}

Nesta seção serão apresentados os resultados dos ensaios realizados. Todos foram realizados no Laboratório de Solos e Pavimentação da Universidade Estadual do Maranhão - UEMA e fazem parte da caracterização geotécnica do solo.

A partir da realização de peneiramento grosso, peneiramento fino e sedimentação foi produzida a curva granulométrica (Figura 11). 
Figura 11 - Curva granulométrica da amostra do solo da feição erosiva.

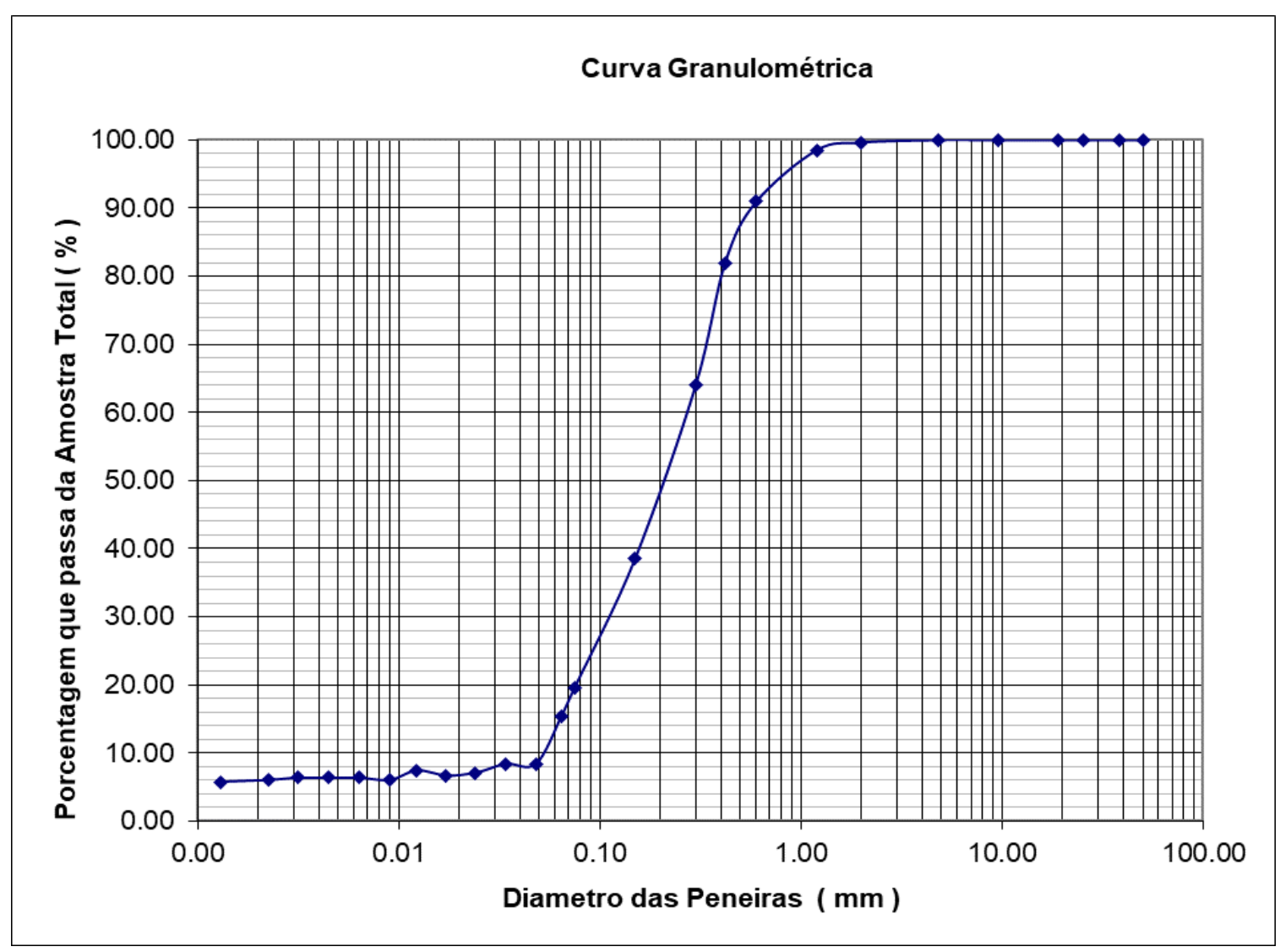

Fonte: Organização dos autores.

O resumo dos Limites de Liquidez e Plasticidade são apresentados na Tabela 4.

Tabela 3 - Resultado do LL e LP da amostra de solo.

\begin{tabular}{|c|c|}
\hline \multicolumn{2}{|c|}{ RESULTADOS LL e LP } \\
\hline Limite de Liquidez (LL): & 16,75 \\
\hline Limite de Plasticidade (LP): & $\mathrm{S} /$ \\
\hline Índice de Plasticidade (IP): & - \\
\hline Índice de Contração (IC): & - \\
\hline
\end{tabular}

Fonte: Organização dos autores.

Em relação aos limites de liquidez e plasticidade, a amostra não apresentou plasticidade, pois o solo é muito arenoso, $80,00 \%$ de areia e $14,00 \%$ de silte. 0 solo foi umedecido gradativamente, mas sempre esfarelava, não permitindo a moldagem do cilindro padrão desse tipo de ensaio. Portando o solo é considerado como não plástico. 


\subsubsection{Avaliação indireta da erodibilidade}

O potencial de erosão dos solos é avaliado aqui com base nas observações de campo e nos resultados dos ensaios realizados de caracterização dos solos. Para isso, faz-se uma interpretação e comparação desses resultados, com os já conhecidos na literatura e com as condições de campo.

Iniciando com a separação de zonas de erodibilidade dentro do triângulo textural proposta por de Araujo e Campos (2013), proposta segundo a qual solos muito erodíveis se concentrariam na região de mais de 50,00\% de areia e menos de $50,00 \%$ de argila. Observa-se na Figura 12 que o solo está dentro da faixa de solos muito erodíveis.

Nas faixas de erodibilidade sugeridas por Mannigel et al. (2002) temos para o solo em estudo que o resultado do fator K (Eq. 2) é de 0,16 t.ha.h/ha.MJ.mm, caracterizando, assim, erodibilidade alta.

Recordando dos valores de LL, LP e IP vê-se que na proposta de Meireles (1967) o solo recebe a classificação de fortemente erodível: Fortemente erodiveis: LL $\leq 21 \%$ e IP $\leq 8 \%$ e $\%$ passa $\# 200 \leq 20 \%$.

Figura 12 - Erodibilidade do solo estudado de acordo com a proposta de Araujo e Campos, 2013.

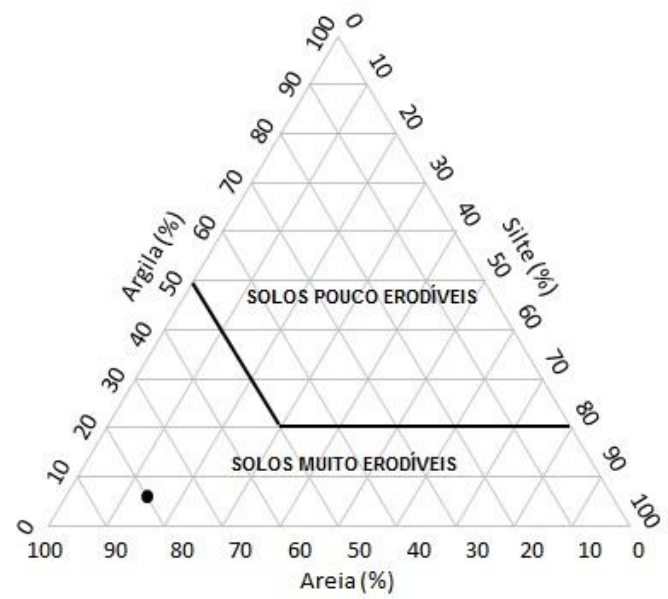

- solo da voçOROCa v01

Fonte: Organização dos autores.

$\mathrm{Na}$ classificação de Santos (2001) que leva em consideração o índice de plasticidade e o coeficiente de uniformidade temos para o solo em estudo $\mathrm{Cu}=0,27$. O critério de utilizar IP ou Cu segue a mesma filosofia da classificação SUCS/ASTM onde é levada em consideração a porcentagem de materiais finos e grossos. Dessa forma o solo é classificado como solo erodível. 
A Tabela 5 sintetiza os resultados de classificação da erodiblidade segundo cada parâmetro geotécnico.

Tabela 4 - Resumo da classificação da erodibilidade através de parâmetros geotécnicos.

\begin{tabular}{|c|c|c|c|c|}
\hline Autor & $\begin{array}{c}\text { Araujo } \\
(2013)\end{array}$ & $\begin{array}{c}\text { Mannigel et al. } \\
(2002)\end{array}$ & $\begin{array}{c}\text { Meireles } \\
(1967)\end{array}$ & $\begin{array}{c}\text { Santos } \\
\text { (2001) }\end{array}$ \\
\hline Parâmetro & $\begin{array}{c}\text { Triângulo } \\
\text { textural }\end{array}$ & $\begin{array}{c}\text { Equação de } \\
\text { Bouyoucos } \\
(1935)\end{array}$ & $\begin{array}{c}\text { LL, IP e \% passa } \\
\# 200\end{array}$ & IP e Cu \\
\hline Classificação & $\begin{array}{c}\text { Solos muito } \\
\text { erodiveis }\end{array}$ & $\begin{array}{c}\text { Erodibilidade } \\
\text { alta }\end{array}$ & Fortemente erodível & $\begin{array}{c}\text { Solo } \\
\text { erodível }\end{array}$ \\
\hline
\end{tabular}

Fonte: Organização dos autores.

\subsection{Uso do Solo}

As principais formas de uso do solo da área são edificações e arruamento. Não foi detectado nenhum tipo de atividade de cultivo. Sobre essas formas de ocupação destacam-se os seguintes impactos: Edificações (Condomínio A): as edificações estão presentes entre a cota 38,00 m e 28,00 m e se estende por 200,00 m. Observou-se que essa área é a de maior declive (10,00\%), portanto, a que favorece uma velocidade maior do escoamento da água. Porém, parte dessa água perde velocidade quando encontra o Condomínio A e parte desce livremente ladeira abaixo como é possível observar na Figura 6. Por ser uma barreira no caminho da água, nesse contexto, a presença de Edificações desfavorecem o fluxo concentrado da água. Porém como essa área é predominantemente impermeável, toda a água que deixa de infiltrar no solo, desce ladeira abaixo amentando o volume de água recebido nas cotas inferiores.

Devido à execução das obras do Condomínio $A$ foram produzidos os seguintes impactos: desmatamentos; movimentos de terra; áreas de empréstimos; impermeabilização do solo devido à construções e compactação (circulação de máquinas); alterações no escoamento das águas devido a escavações e aterros.

As ruas existentes no condomínio A são fruto de um projeto inacabado de obras do PAC, por isso a ruas não estão pavimentadas, não possuem sarjetas e a área edificada como um todo não possui elementos como: bocas de lobo, galerias condutoras e equipamentos dissipadores da energia do escoamento. Dessa forma a água fica livre para fazer o seu curso, não sendo, dessa forma, conduzida. O que se pode notar é que as ruas não têm a infraestrutura necessária de drenagem para combater a ação da água no processo erosivo. 


\subsection{Cobertura Vegetal}

Observando a Figura 3 na perspectiva de extrair informações sobre a cobertura do solo confirma-se o que foi verificado em campo. Observando fotos de datas anteriores (Figura 13 e Figura 14) verifica-se que em 2007 a área encontrava-se totalmente vegetada, enquanto em 2011 já se mostrava desmatada. A vegetação predominante é a vegetação rasteira, médio porte e algumas poucas palmeiras.

Figura 13 - Vista em planta de 2007.

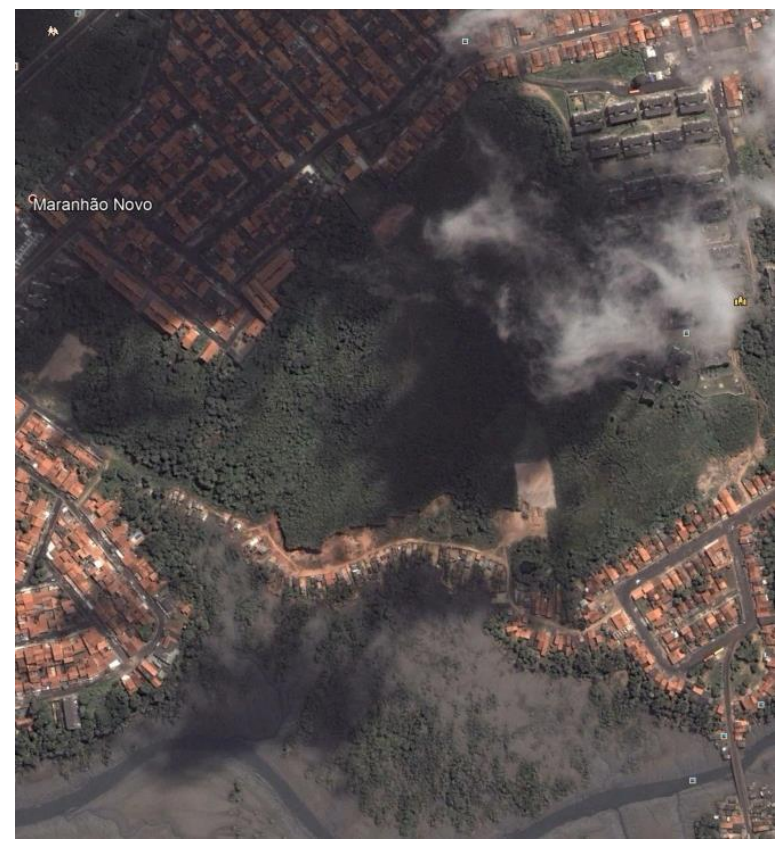

Fonte: Google Earth (2017).

Figura 14 - Vista em planta da área 2011.

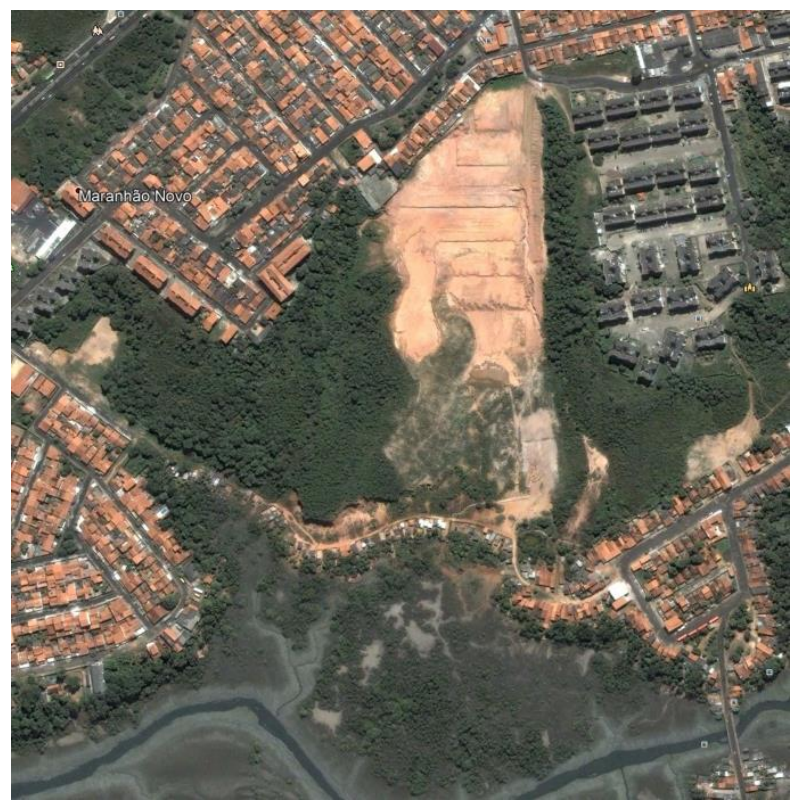

Fonte: Google Earth (2017). 
A falta de uma vegetação contínua no entorno da voçoroca V01 contribui para a fragilidade da área e evolução do processo erosivo. A vegetação existente é muito esparsa e quase não contribui na diminuição do impacto das gotas de chuva. Observa-se ainda que nas regiões onde a voçoroca é mais larga e mais profundo quase não há presença de vegetação.

É necessário fazer algumas considerações com relação à cobertura vegetal. Como podemos observar na Figura 13 e Figura 14 (comparar com a Figura 5) a área já alternou entre um ciclo de totalmente vegetada e quase sem vegetação. Provavelmente esse ciclo já se repetiu outras vezes ao longo do tempo, tanto em um passado próximo (possivelmente queimadas) como em um passado mais distante (por outras causas). Portanto, o diagnóstico da cobertura vegetal será utilizado para extrair informações de suscetibilidade da área no período dessa pesquisa, mas não será utilizado para inferir sobre a gênese do processo erosivo.

\subsection{Susceptibilidade à Erosão}

A sintetize dos resultados sobre a erodibilidade do solo estão resumidas na tabela 6 a fim de obter uma visualização mais compacta dos resultados.

\section{Tabela 5 - Resumo da caracterização do meio físico, caracterização geotécnica e uso e cobertura do solo.}

\begin{tabular}{|c|c|c|c|}
\hline \multirow{3}{*}{ 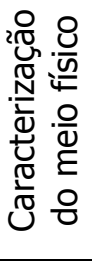 } & Clima & \multicolumn{2}{|c|}{ Existência de chuvas intensas principalmente no início do período chuvoso } \\
\hline & \multirow[t]{2}{*}{ Geomorfologia } & Topografia & $\begin{array}{l}\text { Rampa de 500,00 m favorecendo o aumento de } \\
\text { velocidade da água }\end{array}$ \\
\hline & & Tipo de vertente & Tipo II \\
\hline 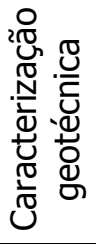 & Solo & \multicolumn{2}{|c|}{$\begin{array}{l}\text { Todos os quatro parâmetros geotécnicos utilizados indicam que o solo } \\
\text { estudado tem um alto potencial erodível }\end{array}$} \\
\hline \multirow{2}{*}{ 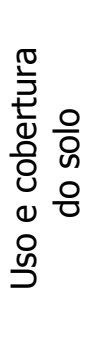 } & Cobertura vegetal & \multicolumn{2}{|c|}{$\begin{array}{l}\text { Alternância de prensa e ausência de vegetação. No entorno da feição erosiva } \\
\text { V01 e algumas regiões de V02 e V03 não há vegetação. }\end{array}$} \\
\hline & Uso do solo & \multicolumn{2}{|c|}{$\begin{array}{l}\text { Edificações e arruamentos inacabados sem infraestrutura necessária para } \\
\text { conduzir a água. A água tende a concentrar o fluxo descendo ladeira a } \\
\text { baixo. }\end{array}$} \\
\hline
\end{tabular}

Fonte: Organização dos autores. 
Clima: foi constatada a presença de chuvas intensas, bem como torrenciais. Como já apresentado, esse tipo de chuva é a que mais contribui para o desenvolvimento do processo erosivo.

Geomorfologia: in loco foi observado que a área em estudo é uma grande rampa com uma extensão de aproximadamente 500,00 m (RUA 11-FIM DE V01) onde a água pode descer livremente ganhando velocidade e concentrando o fluxo. Além disso, essa grande rampa conta com uma diferença de cota de cerca de 30,00 m (RUA 11, 38,00 m e FIM DE V01 8,00 m). O tipo da vertente foi identificado como sendo do Tipo II, concentradora do fluxo superficial.

Solo: a caracterização geotécnica indica que o solo é potencialmente erodível. Tanto os parâmetros que utilizam a granulometria quanto os que utilizam LL e LP produzem o mesmo resultado, indicando sempre que o material é altamente susceptível. Esse fato indica que o solo por si só já é um condicionante potencial para o desenvolvimento do processo erosivo.

Uso do solo: verificou-se que o solo não apresenta infraestrutura necessária para conduzir a água, tanto o Condomínio A quanto o arruamento. A água tende a descer ladeira abaixo concentrando o fluxo, favorecendo dessa forma a evolução do processo erosivo.

Cobertura Vegetal: a cobertura vegetal é densa em algumas regiões e esparsa em outras (principalmente no entorno das feições erosivas). A área já alternou entre totalmente vegetada e sem vegetação. A falta de cobertura vegetal no entorno das feições erosivas contribuem drasticamente para a evolução do processo.

A alta erodibilidade do solo, característica intrínseca verificada pelos parâmetros geotécnicos, somado a chuvas intensas, falta de cobertura vegetal no entorno das feições erosivas e a tendência de concentração do fluxo numa extensa área de declive produz um panorama favorável ao surgimento e evolução do processo erosivo. A voçoroca é uma forma de manifestação da erosão linear, devido ao solo ser potencialmente erosivo, as feições erosivas surgem nos pontos onde o fluxo se concentra, obedecendo a topografia do terreno.

Observa-se ainda que a ação antrópica tem destaque na evolução dos processos erosivos. Isso fica evidente no desmatamento, no lixo que é despejado de forma inapropriada e no próprio uso para edificações. A ocupação do solo gera inevitavelmente 
impactos, porém a ausência de mediadas de minimização desses impactos agrava o cenário.

\section{CONSIDERAÇÕES FINAIS}

Como pode ser observando a Tabela 6, os resultados da pesquisa de investigação multidisciplinar da voçoroca em estudo apontam que todos os fatores condicionantes considerados (meio físico, solo, uso e cobertura dos solos) colaboram para a evolução do fenômeno, podendo-se confirmar que os parâmetros selecionados para a análise multidisciplinar são bons indicativos do processo e, quando tomados em conjunto, permitem identificar com boa confiabilidade áreas suscetíveis à erosão.

A própria existência de feições erosivas, manifesta na forma de voçoroca, já é uma evidência de que o perímetro investigado no bairro do Bequimão possui uma susceptibilidade ao processo erosivo, portanto esta é uma área que valida o método. Uma abordagem tanto pertinente quanto desafiadora seria aplicar este mesmo método em outras áreas em estágios diferentes do processo erosivo ou ainda na ausência de feições erosivas. Isso poderia proporcionar, por exemplo, uma constatação de possíveis limitações de alguns parâmetros bem como a possibilidade de estabelecer pesos entre esses parâmetros, podendo-se proporcionar um maior banco de dados e realizar, assim, uma análise particularizada para cada fator condicionante considerado na análise.

Como corolário desta pesquisa, apresentamos uma possível gênese e uma constatação de como evolui a feição erosiva objeto da nossa análise: a existência de chuvas intensas é característica do clima de São Luís, esse volume de chuva caindo numa área de solo erodível somado a uma topografia caracterizada por declive e uma longa rampa (contribuindo para o ganho de velocidade ladeira abaixo) tendem a produzir feições erosivas. O fluxo concentrado agrava mais ainda o cenário, proporcionando o desenvolvimento de feições erosivas lineares. Devido a falta de cobertura vegetal no local, a água perde pouca energia, aumentando assim o seu impacto a medida que a água desce. A ação antrópica agrava a atividade erosiva, visto que as obras inacabadas no local são desprovidas da infraestrutura necessária para combater a erosão como mecanismos de condução da água e dissipadores de energia. 


\section{REFERÊNCIAS}

ALMEIDA FILHO, Gerson Salviano de et al. Impacto da expansão urbana no desenvolvimento de processos erosivos lineares no Município de Bauru, SP. In: XXI CONGRESSO BRASILEIRO DE ENGENHARIA SANITÁRIA E AMBIENTAL, IV

FEIRA INTERNACIONAL DE TECNOLOGIAS DE SANEAMENTO AMBIENTAL. João Pessoa Anais. ABES, 2001. p. 1-16.

ANGULO, R. J. Relações entre a erodibilidade e algumas propriedades de solos brasileiros. 1983. 168p. Dissertação (Mestrado em Conservação dos Solos) - Universidade Federal do Paraná, Curitiba.

ABNT - Associação Brasileira de Normas Técnicas. Determinação do limite de liquidez. NBR 6459, outubro. 1984a.

ABNT - Associação Brasileira de Normas Técnicas. Determinação do limite de plasticidade. NBR 7180, outubro. 1984b.

ABNT - Associação Brasileira de Normas Técnicas. Peneiras para ensaio - especificação. NBR 5734, outubro. 1984c.

ARAUJO, Rodrigo da Cruz; CAMPOS, Tácio Mauro Pereira. Uso dos ensaios de penetração de cone, desagregação, sucção e resistência à tração para avaliar a erodibilidade. GEOTECNIA. São Paulo. n. 128, p. 67-85, 2013.

BARROS, Wanderbilt Duarte de. A erosão no Brasil. Coleção Mauá-Ministério da Viação e Obras públicas, 1956.

BERTONI, J. O planejador e a utilização dos recursos naturais. Boletim da Federação dos Engenheiros-Agrônomos do Brasil (FEAB), Campinas, 23.p. 1968.

BERTONI, J.; LOMBARDI NETO F. Conservação do solo. Ed. Ícone, São Paulo, SP, 2.ed, 355p. 2008.

BOUYOUCOS, G. J. The clay ratio as a criterion of susceptibility of soils to erosion. Agronomy journal, v. 27, n. 9, p. 738-741, 1935.

CAPUTO, Homero Pinto. Mecânica dos solos e suas aplicações. São Paulo: Livros Técnicos e Científicos Editora Ltda, 6. Ed. vol. 1, 1988.

CASSETI, Valter. Geomorfologia. Fundação de Apoio a Pesquisa-FUNAPE/UFG, 2005.

DREW, David; DOS SANTOS, João Alves. Processos interativos homem-meio ambiente. Rio de Janeiro: Bertrand Brasil, 1994.

FÁCIO, J.A. Proposição de uma metodologia de estudo da erodibilidade dos solos do Distrito Federal. 1991. Dissertação (Mestrado em Geotecnia) - Universidade de Brasília, Brasília, DF. 
FONSECA, AMMCC; FERREIRA, C. S. M. Metodologia para determinação de um índice de erodibilidade de solos. In:

SIMPÓSIO BRASILEIRO DE SOLOS TROPICAIS. Rio de Janeiro. Anais... vol. 1, p. 646-667, 1981.

GOOGLE. Google Earth website. http://earth.google.com/, 2017.

GRAY, Donald H. et al. Biotechnical slope protection and erosion control. Van Nostrand Reinhold Company Inc., 1982.

GUERRA, A.J.T. Processos Erosivos nas Encostas. In: GUERRA, A.J.T.; CUNHA, S.B. (Eds.). Geomorfologia: uma atualização de bases e conceitos. 2.ed. Rio de Janeiro: Bertrand Brasil, 1995.

GUERRA, Antonio José Teixeira; BOTELHO, Rosangela Garrido Machado. Características e propriedades dos solos relevantes para os estudos pedológicos e análise dos processos erosivos. Anuário do Instituto de Geociências. Rio de Janeiro, vol. 19, p. 93-114, 1996.

IWASA, O.Y.; FENDRICH, R. Controle de Erosão Urbana. In: OLIVEIRA, A. M. S., BRITO, S. N. A. (Orgs.). Geologia de Engenharia. São Paulo: Associação Brasileira de Geologia de Engenharia - ABGE 1998. p. 271-282.

JESUS, Andrelisa Santos de. Investigação Multidisciplinar de Processos Erosivos Lineares: Estudo de Caso da Cidade de Anápolis - GO. 2013. 340p. Tese (Doutorado em Engenharia Civil) - Universidade de Brasília, Brasília, DF, 2013.

JORGE, Francisco Nogueira; UEHARA, Kokei. Águas de superfície. In: OLIVEIRA, ANTÔNIO M. DOS SANTOS E BRITO,

SÉRGIO N. ALVES DE. (Orgs.). Geologia de Engenharia. São Paulo: Associação Brasileira de Geologia de Engenharia, 1998. p. 101-109.

JUNIOR, INFANTI. N.; FORNASARI FILHO, N. Processos de Dinâmica Superficial. In: OLIVEIRA, A. MS; BRITO, SNA. (Orgs). Geologia de engenharia. São Paulo: Associação Brasileira de Geologia de Engenharia, p. 131-152, 1998.

LIMA, M.C. Contribuição ao Estudo do Processo Evolutivo de Boçorocas na Área Urbana de Manaus. 1999. Dissertação (Mestrado em Geotecnia) - Universidade de Brasília, Brasília, DF.

LISBOA, G. Serra et al. Análise morfológica das áreas degradadas por voçorocamento na bacia do Rio Bacanga-São Luís/MA. REVISTA GEONORTE, Manaus. vol. 5 n. 14, p. 15-20, 2015.

MAGALHÃES, Ricardo Aguiar et al. Erosão: definições, tipos e formas de controle. In: VII Simpósio Nacional de Controle de Erosão, Goiânia-GO. Anais... Goiânia-GO, vol. 3, p. 1-11, maio de 2001.

MANNIGEL et al. Fator erodibilidade e tolerância de perda dos solos do Estado de São Paulo. Acta Scientiarum. Maringá, vol. 24, n. 5, p. 1335-1340, abr. 2002. 
MARÇAL, M. S. Suscetibilidade à erosão dos solos no alto curso da bacia do rio AçailândiaMaranhão. 2000. 208p. Tese (Doutorado em Geografia) - Universidade Federal do Rio de Janeiro, Rio de Janeiro.

MEIRELES, J. M. F. Erosão de taludes de estradas. In: JORNADAS LUSO-BRASILEIRAS DE ENGENHARIA CIVIL. Anais... São Paulo -Rio de Janeiro. vol. 2, p. 204-211, 1967.

MOREIRA, C.V.R.; PIRES NETO A.G. Clima e Relevo. Oliveira. In: OLIVEIRA, A. MS; BRITO, SNA. (Orgs). Geologia de Engenharia. São Paulo: Associação Brasileira de Geologia de Engenharia - ABGE, 1998.

MORTARI, Diógenes. Caracterização geotécnica e análise do processo evolutivo das erosões no Distrito Federal. 1994. 200p. Dissertação (Mestrado em Geotécnica) Universidade de Brasília, Brasília.

MOTA, S. Planejamento Urbano e Preservação Ambiental. Edições UFC, Fortaleza. 1991.

NUCLEO GEOAMBIENTAL; Laboratório de meteorologia-UGEO/LABMET/UEMA. Informativo climático disponível em: www.nugeo.uema.br, acesso em 15 de novembro de 2017.

PASTORE, E.L. Contribuição ao Tema Geotecnia e Meio Ambiente: Erosão. In: VIII CONGRESSO BRASILEIRO DE

MECÂNICA DOS SOLOS E ENGENHARIA DE FUNDAÇÕES, Porto Alegre. Anais... Porto Alegre, vol. 8, p. 43-54, 1986.

SALOMÃO, Fernando Ximenes T.; IWASA, Oswaldo Yujiro. Erosão e a ocupação rural e urbana. In: BITAR, O.Y. (Org.). Curso de geologia aplicada ao meio ambiente. São Paulo: ABGE/IPT, 1995. p. 31-57.

SANTOS, C. A. Comportamento hidrológico superficial, subsuperficial e a erodibilidade dos solos da região de Santo Antônio do Leite, distrito de Ouro Preto - Minas Gerais. 2001. 107p. Dissertação (Mestrado em Geologia) - Universidade Federal de Ouro Preto, Ouro Preto, MG.

SANTOS, Roberto Márcio Macedo dos. Caracterização Geotécnica e Análise do Processo Evolutivo das Erosões no Município de Goiânia. 1997. Dissertação (Mestrado em Geotecnia) - Universidade de Brasília, Brasília, DF.

SATHLER, Rafael et al. Caracterização de voçorocas na ilha do Maranhão. Anuário do Instituto de Geociências, Rio de Janeiro, vol. 32 n. 1, p. 34-45, 2009.

SILVA, Antonio Soares da. Análise morfológica dos solos e erosão. In: GUERRA, A. J. T.; SILVA, A. S; BOTELHO, R. G. M. (Orgs.). Erosão e conservação dos solos: conceitos, temas e aplicações. Rio de Janeiro: Bertrand Brasil, 3. ed. 2007.

SILVA, T. Pereira et al. Análise morfológica dos solos nas voçorocas araçagy I e II no município de São José de Ribamar. REVISTA GEONORTE, Manaus, vol. 5 n. 14, p. 21-27, 2015. 
TROEH, FREDERICK R. Landform equations fitted to contour maps. American Journal of Science, v. 263. n. 7, p. 616-627, 1965.

VILAR, O.M.; PRANDI, E.C. Erosão dos solos. In: Ferreira, A. A., Negro Júnior, A., Albiero, J. H., \& Cintra, J. C. A. (Orgs.). Solos do interior de São Paulo. São Carlos: ABMS/ EESCUSP, 1993. p.177-206.

VILLELA, Swami Marcondes; MATTOS, Arthur . Hidrologia Aplicada. McGraw-Hill, 1975.

WISCHMEIER, W. H.; SMITH, D. D. Predicting rainfall erosion losses - a guide to conservation planning. Washington, USDA, Agricultural Handbook, (537). 1978.58p. 